\title{
Emission Trading Schemes in China and the European Union, Achievements and Challenges
}

\author{
Mingshun Zhang ${ }^{*}$, Zelu Liu ${ }^{1}$, Wei Jin ${ }^{2}$, Meine Pieter van Dijk ${ }^{3}$ \\ ${ }^{1}$ Beijing Climate Change Response Research and Education Centre, Beijing University of Civil Engineering and Architecture \\ (BUCEA), Beijing, China \\ ${ }^{2}$ Hebei University of Environmental Engineering, Qinhuangdao, China \\ ${ }^{3}$ International Institute of Social Studies (ISS), Erasmus University Rotterdam, Rotterdam, Netherlands \\ Email: ${ }^{\star}$ zhangmingshun@bucea.edu.cn
}

How to cite this paper: Zhang, M.S., Liu, Z.L., Jin, W. and van Dijk, M.P. (2018) Emission Trading Schemes in China and the European Union, Achievements and Challenges. Low Carbon Economy, 9, 33-44.

https://doi.org/10.4236/lce.2018.91003

Received: February 19, 2018

Accepted: March 24, 2018

Published: March 27, 2018

Copyright $\odot 2018$ by authors and Scientific Research Publishing Inc. This work is licensed under the Creative Commons Attribution International License (CC BY 4.0).

http://creativecommons.org/licenses/by/4.0/ Open Access

\begin{abstract}
A comparison of the European Union (EU) and China's emission trading schemes (ETS) is made and we analyze a field survey concerning the pilot ETS in China. The comparison shows that EU's carbon market is relative mature, given that EU has adopted more flexible and market based measures for its ETS. In China there are more governmental interventions to make the ETS work, but there is lack of a legal foundation and market measures for China's ETS. The survey yielded information on the attitudes of the participants towards ETS and the linkages between carbon price and the actions by ETS participants to diminish carbon emissions. The survey results show that most participants are willing to participate in ETS and that the ETS does have positive impact on the reduction of $\mathrm{CO}_{2}$ emission. However China is not yet well prepared to move from seven small pilot ETS to a nationwide ETS, since relevant laws and regulations are not well formulated. This also explains why there are much governmental interventions for the 7 pilot ETS in China. The survey result shows that the existing carbon price in China is too low to mobilise industrial investment in abatement technology.
\end{abstract}

\section{Keywords}

Achievements, Challenges, China, $\mathrm{CO}_{2}$ Emission Rights Trading Schemes, The European Union

\section{Introduction}

The Chinese president has made it clear during the Paris climate change conference in December 2015 that China's $\mathrm{CO}_{2}$ emission will decrease (reach its peak) by 2030 in absolute term and will decrease by $18 \%$ by 2010 in relative 
terms. One suggestion to achieve these goals is to create an integrated national $\mathrm{CO}_{2}$ emission trading system (ETS), which is to be the biggest ETS in the world, bigger than the ETS of the European Union (EU). Before launching the nationwide ETS, China has experimented with ETSs in seven cities and provinces since 2013. The question is whether three years after creating a relatively small market for $\mathrm{CO}_{2}$ emissions in China (in terms of quantities traded and the number of participants), can the market become a national one in just two or three years?

Increased $\mathrm{CO}_{2}$ emissions contribute to climate change. Carbon emission trading aims to promote the control of one type of greenhouse gas (GHG) emission, $\mathrm{CO}_{2}$. Use is made of $\mathrm{CO}_{2}$ emission rights trading to assure efficient investments in reduction of $\mathrm{CO}_{2}$. If the cost of investments are higher than the cost of $\mathrm{CO}_{2}$ emission trading rights preference will be given to buying these rights. The idea behind the system is however, that the market price for $\mathrm{CO}_{2}$ emission trading rights is so high that efficient investments in $\mathrm{CO}_{2}$ emission reduction are made if that is cheaper than buying the rights, which would often be the case in developing countries where very few investments in cleaner production have been made so far. This implies that if the $\mathrm{CO}_{2}$ emission trading rights are cheap it is convenient for the enterprise to buy them and to refrain from environmental investments.

In this paper we compare the key building blocks of both EU ETS and China's seven pilot ETSs and analyse the weak points of both EU ETS and China ETS [1]. Which factors determine whether this market will be a success in terms of handling substantial amounts of $\mathrm{CO}_{2}$ emissions rights and at a reasonable price? We conducted a field survey of Beijing pilot ETS in the $2^{\text {nd }}$ half of 2016, while China was preparing the nationwide ETS. This survey was distributed to 452 participants of Beijing ETS and 378 have replied the survey. The participants are selected, based on their historical annual $\mathrm{CO}_{2}$ emission of 10.000 tons. Those selected 452 participants are compulsorily involved in the existing Beijing ETS. The survey includes two parts. Part 1 aims at understanding whether participants are prepared already in participating in ETS through evaluating their attitudes towards the ETS. Part 2 aims at answering a key question of ETS: what is the price of $\mathrm{CO}_{2}$ at which investors prefer to invest in abatement technology?

We have extensive information on China [2] and the EU [3]. The Asian Development Bank $(\mathrm{ADB})$ published a very interesting report comparing emission trading schemes in Asia, using the experience of China, Kazakhstan, India, Indonesia, Thailand and Vietnam. Our objective is to come up with recommendations for China how to integrate the national $\mathrm{CO}_{2}$ market, based on experiences elsewhere in the world.

\section{A Systematic Comparison between EU ETS and China ETS}

The EU ETS is the earliest carbon market in the world. It has been implemented in three phases and it is now in the preparation of the fourth phase. China

lunched 7 small pilot carbon markets in two provinces of Guangdong and Hubei 
and five cities of Beijing, Shanghai, Tianjin, Chongqing and Shenzhen in 2013 [4]. The EU ETS has been the key reference for China's seven pilot carbon markets for designing their ETS system and thus it is of great interest to compare the EU and Chinese ETS in a systematic way and the aim is to identify key factors for China developing an integrated one national ETS by learning lessons from EU ETS and China's seven pilot ETS.

ADB [2] characterizes each ETS in 10 building blocks that could explain an ETS in a systematic way. There are similarities in some building blocks and, in this paper we applied the most important six building blocks for comparing the EU-China ETS: coverage, targets and caps, allocation system, monitoring and verification, flexible measures and measures to manage market supply and the price (Table 1).

The EU has the largest ETS in the world at the moment with a volume of 1.7 2.0 billion tons of $\mathrm{CO}_{2}$ eq. The EU ETS covers all GHGs and about 11,000 installations are involved. China's seven pilot ETSs and its future national ETS will only cover $\mathrm{CO}_{2}$, mainly due to the fact that no data are available concerning other GHGs. In addition, China is not yet prepared for trading of non GHGs, given to lack of methodology and historical data collected. China launched its national ETS and it is going to be the largest ETS in the world with the volume of 3 - 4 billion tons of $\mathrm{CO}_{2}$, which will be double the EU carbon market. The main difference in the type of participants between EU and China is that, in the EU these are installations and all GHGs and in China companies and $\mathrm{CO}_{2}$ only. The main reason is that EU has the statistics on GHG emissions at the installation level, however China has only as the data on company level.

With regard to the difference in targets and caps, the EU sets absolute targets and caps in tons of GHGs. China sets up relative target in tons of $\mathrm{CO}_{2}$ per GDP and accordingly calculating the cap in tons of $\mathrm{CO}_{2}$. The main reason is that the EU has reached its peak already and GHG emissions are decreasing. China, however, has not yet reached its peak and it is estimated that China's peak of $\mathrm{CO}_{2}$ emission will be around 2030. Thus the absolute amount of $\mathrm{CO}_{2}$ emission is still increasing in China and thus it is difficult to include the absolute amount of GHG in the defining targets.

China learns from EU experience in allocating allowances. Given the disadvantage of free allocations of trading rights in the EU in phase I of the ETS, China adopts a combination of free allocation and auctioning for its seven pilot stage systems and the system will be adopted in the future national ETS as well [5]. However, it seems that EU has much more rights allocated by auctioning. In phase III, $43 \%$ of the allowances are auctioned and in the power sector everything is auctioned in the EU. In China, however, only $5 \%-10 \%$ of the allowances is auctioned in the national ETS, which is compared to the level of the EU ETS in phase II. The low percentage of allowances auctioned can be explained by the fact that both China's national and local governments are worrying that a higher level of auctioning may have negative impacts on industrial competitiveness in the 
Table 1. Comparison of the European Union and China's emission trading scheme.

\begin{tabular}{|c|c|c|}
\hline Building block & EU ETS & $\begin{array}{c}\text { China existing seven pilot ETSs } \\
(2013-2016)\end{array}$ \\
\hline Coverage & $\begin{array}{l}\text { Covers } 28 \text { EU member states and Iceland, Liechtenstein, and } \\
\text { Norway-over 11,000 installations. Largest ETS in the world. } \\
\text { GHG: carbon dioxide }\left(\mathrm{CO}_{2}\right) \text {, methane, nitrous oxide }\left(\mathrm{N}_{2} \mathrm{O}\right) \text {, } \\
\text { sulphur hexafluoride, hydro fluorocarbon (HFCs), per } \\
\text { fluorocarbons, and nitrogen trifluoride. } \\
\text { Sectors: power stations and other combustion plants with } \geq 20 \\
\text { MW thermal rated input, oil refineries, coke ovens, iron and } \\
\text { steel, cement clinker, glass, lime, ceramics, pulp, paper and } \\
\text { board, aluminum, bulk organic chemicals, ammonia, } \\
\text { nitric/adipic/glyoxylic acid production, hydrogen, soda ash, } \\
\text { carbon black, } \mathrm{CO}_{2} \text { capture and storage. In aviation, limited to } \\
\text { flights within the European Economic Area until } 2016 \text {. }\end{array}$ & $\begin{array}{l}\text { Chongqing, Shanghai, Tianjin, Guangdong } \\
\text { Province: Installations' annual emissions above } \\
20,000 \text { t } \mathrm{CO}_{2} \text { equivalents, in the power, iron, } \\
\text { steel, ferrous metals, chemical and } \\
\text { petrochemicals, cement sectors where present. } \\
\text { Shanghai further includes airlines, harbours, } \\
\text { airports, railways, and commercial sector, with } \\
\text { Tianjin including residential buildings. } \\
\text { Hubei Province: Installations with annual } \\
\text { energy consumption above } 60,000 \text { tce, targeting } \\
\text { similar sectors as above. } \\
\text { GHG: only } \mathrm{CO}_{2} \text {. }\end{array}$ \\
\hline Targets and caps & $\begin{array}{l}\text { Targets relative to } 1990 \text { and absolute cap: } \\
\text { i) Phase I (PI) - 2005-2007: Not applicable, } 2298.5 \mathrm{Mt} \mathrm{CO}_{2} \mathrm{eq} \\
\text { ii) Phase II (PII) - 2008-2012: } 8 \% \text {, 2086.5 } \mathrm{Mt} \mathrm{CO}_{2} \mathrm{eq}\left(1^{\text {st }} \text { Kyoto }\right. \\
\text { Protocol commitment period) } \\
\text { iii) Phase III (PIII) - 2013-2020: } 20 \%, 1777 \mathrm{Mt} \mathrm{CO}_{2} \mathrm{eq} \\
\text { iv) Phase IV (PIV) - 2021-2028: } 40 \% \text {, Not applicable }\end{array}$ & $\begin{array}{l}\text { Targets: All areas covered have intensity-based } \\
\text { targets for economy-wide GHG emission } \\
\text { reduction, ranging from } 17 \% \text { - } 21 \% \text { reduction } \\
\text { by } 2015 \text { from } 2010 \text { levels, which are set at the } \\
\text { national level. } \\
\text { Cap: Following intensity-based targets and } \\
\text { economic or sector growth projections, all ETSs } \\
\text { have absolute caps, which in some cases permit } \\
\text { growth in emission levels. The first compliance } \\
\text { period is timed with the Preparatory stage, } \\
2013-2016 \text {, lasting } 2 \text { - } 3 \text { years, depending on the } \\
\text { start date in each province. The volume of the } \\
\left.\text { caps in Mt } \mathrm{CO}_{2} \text { eq for } 2013 \text { were: Beijing ( } 50\right) \text {, } \\
\text { Chongqing (125), Shanghai (160), Shenzhen } \\
\text { (33), Tianjin (160), Guangdong Province (388), } \\
\text { and Hubei Province (324). }\end{array}$ \\
\hline $\begin{array}{l}\text { Allocation of } \\
\text { allowances and carbon } \\
\text { leakage }\end{array}$ & $\begin{array}{l}\text { PI and PII: decentralized mainly free allocation, minimum } \\
\text { auctioning requirements } 5 \% \text { and } 10 \% \text {. } \\
\text { PIII: } 43 \% \text { allowances auctioned. Fully auctioned in power } \\
\text { sector. (At least half of auctioning revenues are required to be } \\
\text { used for climate and energy-related purposes.) Full auctioning } \\
\text { is required by } 2027 \text {. } \\
\text { Carbon leakage is mitigated by free allocation to certain sectors } \\
\text { considered vulnerable, such as manufacturing and aviation, } \\
\text { based on harmonized benchmarks. The proportion of } \\
\text { allowances auctioned decreases over time. }\end{array}$ & $\begin{array}{l}\text { Plans: Allocation plans are established at a } \\
\text { national level and implemented by provincial } \\
\text { authorities, which may be more stringent with } \\
\text { regards to free allocation. } \\
\text { Free allocation: Allowances are mostly freely } \\
\text { allocated, using benchmarking methodologies } \\
\text { based on different base years. } \\
\text { Auctioning: Guangdong, Chongqing and Hubei } \\
\text { intended to use auctioning for a small } \\
\text { percentage, but only Guangdong has done this } \\
\text { so far. } \\
\text { Future China national ETS: combination of free } \\
\text { allocation and auctioning. }\end{array}$ \\
\hline $\begin{array}{l}\text { Monitoring, reporting } \\
\text { and verification }\end{array}$ & $\begin{array}{l}\text { Installations are required to have an approved monitoring plan } \\
\text { and monitor and report their emissions according to the } \\
\text { monitoring and reporting regulations. Third-party verification } \\
\text { of an annual emissions report is required. Verified annual } \\
\text { emissions reports are due } 31 \text { March of the subsequent year, and } \\
\text { it is required to surrender the equivalent number of allowances } \\
\text { by } 30 \text { April. }\end{array}$ & $\begin{array}{l}\text { Monitoring, reporting, and verification (MRV) } \\
\text { procedures in accordance with respective } \\
\text { guidelines for each jurisdiction at the sectoral or } \\
\text { installation level. Guidelines for verification of } \\
\text { these emissions exist in many ETSs. Most of } \\
\text { these guidelines have been improved during } \\
\text { this pilot phase. Guidelines and oversight of } \\
\text { qualification of verification bodies is done at the } \\
\text { national level and implemented at the } \\
\text { provincial level. }\end{array}$ \\
\hline
\end{tabular}




\section{Continued}

Flexible measures

(banking and

borrowing, credit

mechanisms or offsets

and linking)
Banking was not permitted between phases PI and PII. It was permitted from PII to PIII, and is going on

Borrowing: Not permitted

Linking: Norway, Iceland, and Liechtenstein linked in 2008. Negotiations with Australia launched in 2012 but repealed in 2014, with Switzerland under discussion Offsets: Quantity restrictions: in PI determined by member states. Subsequently, offsets limited to $50 \%$ of compliance 2008-2020. Quality restrictions: credits from Kyoto Protocol mechanisms (CDM and JI) permitted from PII.
Measures to manage market supply \& price
Back-loading of allowances: To deal with structural surplus, auctioning of $900 \mathrm{~m}$ allowances was postponed from 2014-2016 until 2019-2020.

Market stability reserve: To manage a structural surplus, from 2019, if surplus allowances are above a maximum threshold, they will be placed in a reserve and only released when surplus drops below minimum threshold. Back-loaded allowances will be placed in the reserve.

Offset restrictions: Due to flooding of the market, JI offsets delivered after 2012 were restricted.
Banking: Permitted between years in pilot period, except in Hubei province.

Borrowing: Prohibited.

Offsets: Qualitative restrictions: No international credits accepted. All ETSs accept domestic credits, with Beijing requiring 50\% and Guangdong 70\%, of credits be sourced locally, and Chongqing requiring credits be sourced through their voluntary or forest schemes. Quantitative restrictions: 5\% - 10\% of compliance can be met by credits.

Linking: Efforts will be made to explore options for linking with other markets in the Stability Phase (post-2020).

Strategic reserve: Shenzhen, Guangdong, and Hubei have established a strategic reserve for price management. Such a reserve is also intended in Shanghai, Beijing, Chongqing, and Tianjin have not yet declared clear rules for price management.

Auction and buy-back of allowances: Beijing and Tianjin intend to use auctioning and buy-back of allowances to control supply and prices.

Source: [2] [3]. ${ }^{1}$ However, from 2004, no nuclear, land-use changes, forestry and large hydro projects were included; from 2010 no HFC-23 and N2O industrial gas project were permitted.

short period.

The EU and China have suggested quite similar monitoring, reporting and verification (MRV) systems. However, the numbers of third parties who are qualified for conducting MRV are quite limited and the lack of MRV capacity may be one of barriers for China implementing national ETS.

It seems that EU is allowing more flexible measures, allowing for example banking and borrowing, credit mechanisms or offsets and linking. This is due to that EU has more than 10 years' experience with its ETS and China is still at an initial stage of its ETS. China's strategy is learning by doing while promoting the ETS and it is expected that more flexible measures will be adopted in the future in China.

The EU takes more measures to manage market supply and price and those measures are market-based. There are more government interventions in the ETS market in China. As an example, governments of Beijing and Tianjin buy-back the allowances when the carbon prices are is getting lower for stabilization of the market. We argue that both Chinese national and local governments will play a more active role in China's future national ETS. Improving sustainability of ETS will be an issue in China, since an ETS is a market instrument and the market should play the dominant role.

\subsection{The Envisaged New System in China}

China launched its national unified ETS at the end of 2017. The national ETS 
concerns about 7000 companies with an annual energy consumption of 10.000 tce. In its design stage, eight sectors will be involved in China's national ETS, such as petrochemical, chemical, building materials, iron and steel, ferrous metals, paper-making, power station and aviation. Given to the short preparations, however, the national ETS has involved only the sector of power generations. It is estimated that $50 \%$ of total $\mathrm{CO}_{2}$ emissions will be included in China's ETS. The China Certified Emission Reduction (CCER) can be traded. In the future, China national ETS will deal with between $3000-5000 \mathrm{Mt} \mathrm{CO}_{2}[6]$.

\subsection{Weak Points in the Functioning of the ETS in the EU and in China}

The following Table 2 shows the weak points of EU's and China's pilot ETS.

\subsection{Oversupply and Consequence of Market Response}

The EU ETS has seen oversupply of allowances in each of its three phases to date, but the cause and impact has been different for each phase. In the 3 years of phase I, the oversupply of allowances was the result of a number of factors. Firstly, member states generally lacked verified baseline emissions data when establishing their caps in their national allocation plans (NAPs), and baseline emissions were generally overstated. Secondly, there was not an emission reduction target for member states in the EU; at that time, caps were largely established against a business-as-usual basis with limited ambition. Thirdly, the decentralized approach to cap setting meant that member states had an incentive and flexibility to seek to protect their own industries, and retrospectively, allocations appeared generous relative to emissions. In phase II the caps were still developed through the member state NAPs (as in phase I); although there was

Table 2. Weak points of EU's and China's pilot ETS.

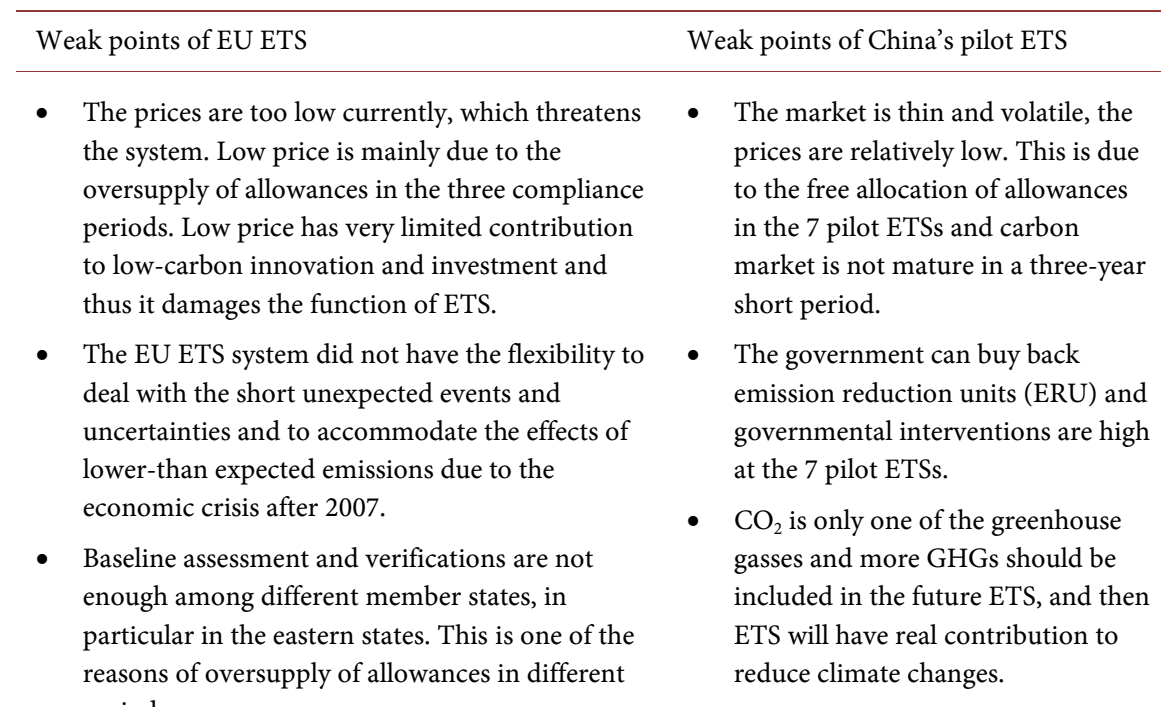

Source: [2] [3] 
more robust application of the principles for cap setting by the European Commission, which had the responsibility to approve NAPs. However, the economic crisis caused a downturn in industrial activity and consequently reduced emissions, with large surpluses for each year after 2008, resulting in the accumulation of a large surplus by the end of Phase II. The surpluses continue well into phase III, with the economic slowdown continuing to contribute to the oversupply of allowances relative to emissions.

These surpluses remove the need for abatement to meet the caps, and naturally the market has responded with a very low or zero-carbon price. Figure 1 shows the market responding on the oversupply of allowance. Phase I carbon prices peaked at over $€ 30$ per metric ton in 2007 influenced by the rising gas prices and fell to nearly zero by the end of the same year, because surpluses could not be carried over into phase II. In phase II a more ambitious cap taking into account verified baselines and more harmonized and stringent national cap setting processes lead to a strong initial carbon price, peaking at $€ 30$ per $\mathrm{Mt}^{\mathrm{CO}_{2}}$ in July 2008, but again prices fell to much lower levels as the oversupply position became clearer [7].

China has learnt from the experience of EU ETS on oversupply of allowance and has taken the following measures to avoiding oversupply and to stabilize the carbon price.

1) Applying multi-approaches of grandfathering and benchmarking for baseline assessment and adopting centralized approach to cap setting in the seven pilot ETSs;

2) More governmental intervention to the EST. Local government in the 7 pilot ETS have reserved certain amount of allowances that will be used for stabilizing the market;

3) Setting more ambitious target and combing free allocations and auctions.

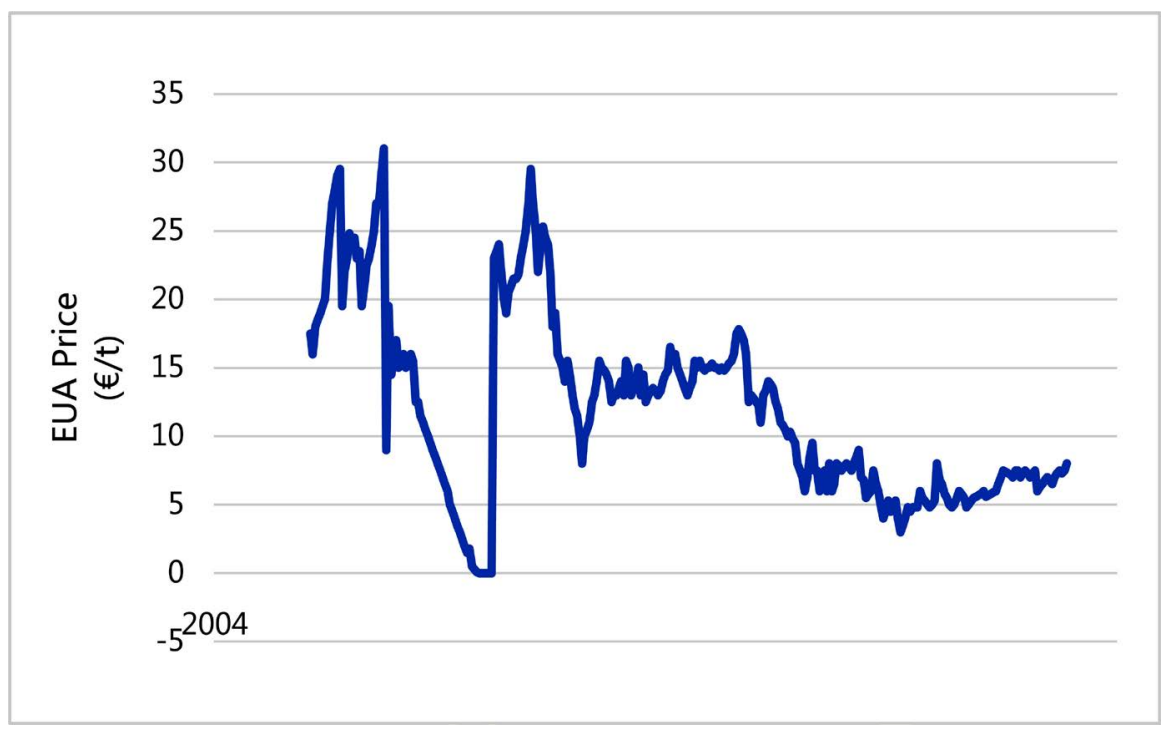

Source: [2].

Figure 1. Evolution of European Union Allowance Prices from 2005-2015. 


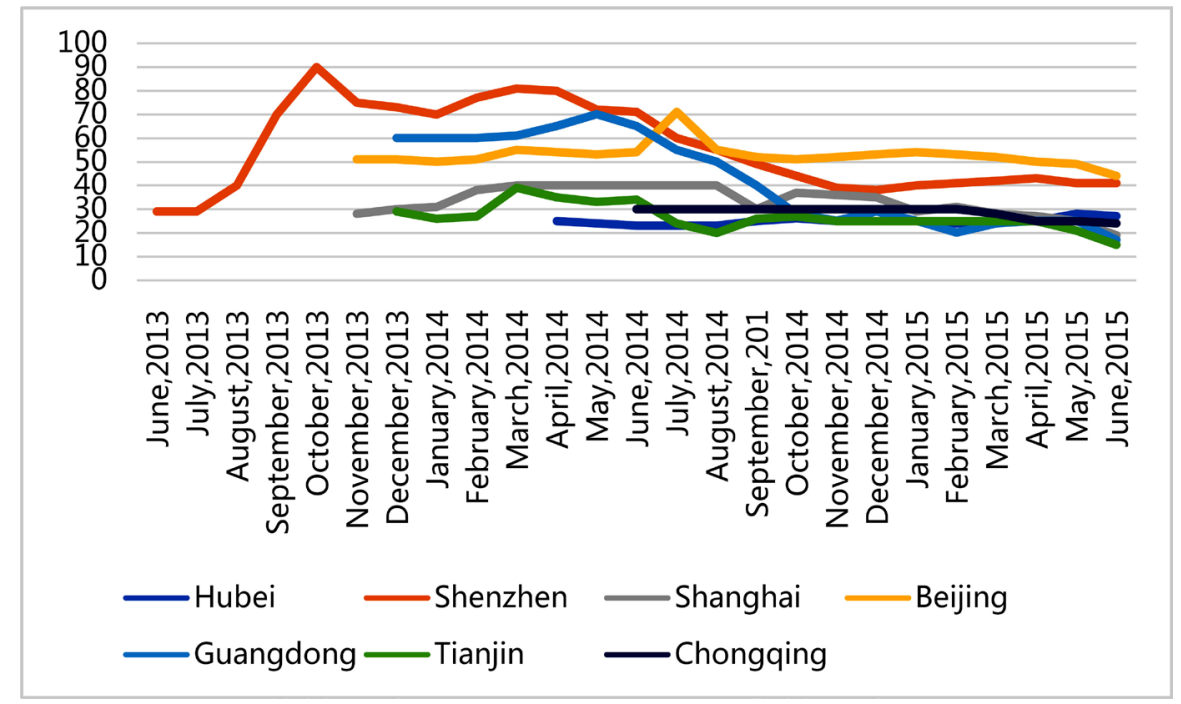

Source: Carbon K-Line http://k.tanjiaoyi.com/, consulted 19-9-2016.

Figure 2. Evolution of China's 7 pilot ETSs Allowance Prices from 2005-2015.

During the three years of 7 pilot ETS (2014-2016), China has also encountered a slightly more economic slowdown, which has limited impacts on ETS. Thus the carbon price in the 7 pilot ETS in China was quite stabilized, as compared to the EU ETS. Figure 2 shows that there are huge differences between the prices of trading at earlier emission trading schemes stage in the seven pilot emission trading schemes. Among them, prices in Shenzhen were the highest and the prices in Hubei are the lowest. After the initial stage of emission trading schemes, differences in prices among seven pilot ETSs is getting smaller and smaller.

\section{Attitudes of Participants towards ETS: A Survey in Beijing ETS}

Attitudes of participants towards ETS are assessed based on the following seven questions. Each participant is asked to answer these seven questions by scoring 0 (bad) - 10 (best). The surveys have been distributed to 452 participants in Beijing and 378 replies have been collected. In addition to the survey, we have interviewed 12 participants for knowing more about their answers behind. The survey result is presented in Table 3.

Table 3 indicates that most participants are really willing to participate in ETS and they consider the ETS could stimulate participants to reduce $\mathrm{CO}_{2}$ emissions. The high willingness is in line with ETS literature, which points to that ETS as a market instrument provides flexibility of either by taking low carbon actions or buying allowances for participants to comply with the targets. Table 2 shows that China is not yet sufficiently prepared to move from the seven small pilot ETS to a nationwide ETS, since the relevant laws and regulations are not in place. This can also explain low score in governmental intervention, given to the fact that there are too much governmental interventions in the existing pilot 
Table 3. Attitudes of participants towards the existing emission trading scheme in Beijing $(\mathrm{N}=378)$.

\begin{tabular}{lc}
\hline \multicolumn{1}{c}{ Questions } & $\begin{array}{c}\text { Average score } \\
(0-10)\end{array}$ \\
\hline 1) Are you willing to participate in ETS? & 8.5 \\
2) Are you satisfied with the existing institutional infrastructure of ETS operation? & 7.5 \\
3) Are the ETS regulations and laws enough and effective in supporting ETS? & 4.8 \\
4) Do you have all necessary internal capacities (monitoring, reporting, etc.) in & 5.7 \\
participating in ETS? & 9.2 \\
5) Do you think that the existing ETS could stimulate participants to reduce $\mathrm{CO}_{2}$ & \\
emissions? & 6.5 \\
6) Are you satisfied with the services of the MRV consultancy companies? & 4.3 \\
7) How do you evaluate the governmental intervention to the existing ETS? & 6.6 \\
\hline
\end{tabular}

Source: primary data, 2016.

ETS. In addition, internal capacity building of participants is necessary and needed for future nationwide ETS of China.

\section{Impact of China's ETS on Low-Carbon Investment: A Survey in Beijing ETS}

$\mathrm{A} \mathrm{CO}_{2}$ emission trading system is one of the carbon pricing instruments besides taxes, trading and crediting [8] which aims at stimulating low carbon development at the most cost-effective way. EU experiences show that over-allocation of allowance may result in low carbon prices and may damage the ETS. The problems associated with over-allocation, low carbon prices, and price volatility in the existing systems demonstrate that both systems lack the flexibility to respond to unexpected changes and events and fail to provide long-term consistent incentives for low-carbon investment. By learning from experience of the EU ETS, it is crucial for China set up a fair and ambitious cap that may avoid lower carbon price and stimulate low-carbon investment. This paper has conducted a survey in Beijing for asking about 452 participants that are being involved in the existing Beijing pilot ETS (one of the China's seven pilot ETSs). The survey aimed at building up linkages between low-carbon actions/investments and carbon price. Among the 452 participants in Beijing pilot ETS, 378 has replied and most of them (more than $80 \%$ ) are electricity and heat production companies and key industrial energy-intensive companies [9]. The survey included the following five questions:

1) ETS will have a positive effect on awareness and you will not take any investment on low-carbon actions, when the carbon price is less than Chinese Yuan.

2) You will take housekeeping actions with very low low-carbon investment, when the carbon price is more than Chinese Yuan.

3) You will take low-carbon investment with payback time (PBT) of less than 
2 years, when the carbon price is more than Chinese Yuan.

4) You will take low-carbon investment with payback time (PBT) of 3 - 5 years, when the carbon price is more than Chinese Yuan.

5) You will take high low-carbon investment on $R \& D$, when the carbon price is more than Chinese Yuan.

The following Figure 3 shows the survey results:

Figure 3 shows that ETS will only contribute to carbon awareness raising when the carbon price is less than 14.7 Chinese Yuan per ton $\mathrm{CO}_{2}$. When the carbon price is between 27.3 - 45.8 Chinese Yuan per ton $\mathrm{CO}_{2}$, ETS will stimulate low-carbon actions/investment on housekeeping and investment of less than 2 years PBT. ETS will contribute to low-carbon investment (middle term and long term investment) when the carbon price is more than 88.6 Chinese Yuan per ton $\mathrm{CO}_{2}$. High investment on low-carbon R\&D could be stimulated by ETS only if the carbon price is more than 220.6 Chinese Yuan per ton $\mathrm{CO}_{2}$. These survey results are in line with the estimation of China National development and Reform Commission (NDRC) who is the China central government in charge of carbon and climate issues [10]. Jiang [11] from the Department of Climate of NDRC estimates that $\mathrm{CO}_{2}$ prices in China's ETS may reach 240 Chinese Yuan per ton in 2020 and then the ETS will really play crucial role in mobilising low-carbon $\mathrm{R} \& \mathrm{D}$ and investing abatement technologies.

China launched a unified national ETS in 2017, and it is estimated that the price per ton of $\mathrm{CO}_{2}$ will be 30 - 40 Chinese Yuan. Based on the survey mentioned-above, the price of 30 - 40 Chinese Yuan ton may stimulate participants' awareness raising about carbon emissions, while for taking housekeeping actions and conducting low low-carbon investment with short pay back times (PBT less than 2 years) the price has to be higher. The current prices have very limited contribution to low-carbon R\&D and to investments in abatement technologies [12] [13].

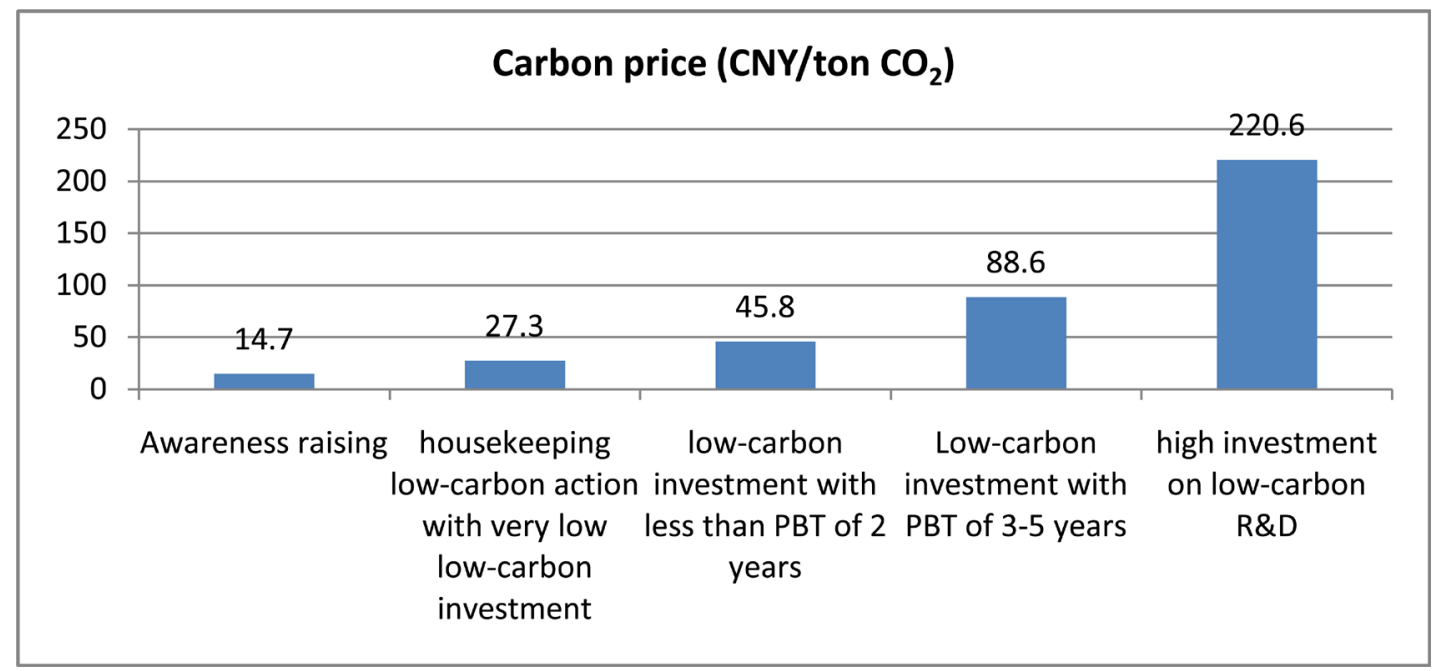

Source: Primary data, 2016.

Figure 3. Carbon price Vs low-carbon actions $(\mathrm{N}=378)$. 


\section{Conclusions}

There are many differences between EU ETS and China's 7 pilot ETSs. It seems that carbon market is relatively mature in EU, while China's carbon market is still in a very early stage of development. Survey findings reported in this paper indicate that there is too much governmental intervention in the ETS and there is lack of flexible and effective measures to manage market supply and price in China. Incomplete policy framing and lack of legal foundations are also barriers for China moving from small pilots to a nationwide ETS.

The EU ETS covers all GHGs and more than $80 \%$ of emissions, while China's future nationwide ETS will only cover $\mathrm{CO}_{2}$ and half of its national emission. Still, China is going to be the largest carbon market by replacing EU market in 2018. The EU is facing challenges of member states with quite different economic scale and industrial development and such differences have created many barriers for the effective performance of EU ETS. China is also facing challenges of differences of economic scale and industrialization level between eastern China and western China [14].

Free allocation and oversupply of allowances have been the key factor for very lower carbon prices in the EU ETS. Both the EU and China are practicing low carbon-price that is a threat to the functioning of ETS. Level and stabilization of carbon price are crucial for well-functioning of ETS. China's carbon price in the future nationwide ETS will fall to 25 - 45 Chinese Yuan per ton, which may contribute to low-carbon actions of housekeeping and low-investment with short PBT, based on the field survey of this article. However, after 2020, when China sets up more high ambitions, the carbon price will increase and then ETS will play a real role in stimulating low-carbon research \& development.

\section{Recommendations}

Practices of both EU ETS and China's 7 pilot ETSs have created the need for improving existing emissions trading markets as well as the need to learn lessons from the strategic development of future markets. It is recommended that China's national ETS should set up a long term ambitious caps to create constant demand on emission reduction, and in the meanwhile setting up instruments for dealing with unexpected changes and uncertainties. Strong ambition is critical to ensure proper functioning of an ETS. Avoiding over allocation of allowances is the key to establishing net market demand and a strong carbon price. Multi-approach baseline assessments are also crucial and the baseline emissions must be cross-checked and verified. Linking ETS and low-carbon initiatives is necessary and thus it is recommended that China's future ETS should set up specific funds to support low-carbon innovations. The EU's two funds of Innovation Fund and Modernisation Funds are good examples to learn from for China.

\section{References}

[1] Van Dijk, M.P. (2015) Measuring Eco Cities, Comparing European and Asian Ex- 
periences: Rotterdam versus Beijing. Asia Europe Journal, 13, 75.

https://doi.org/10.1007/s10308-014-0405-7

[2] ADB (2016) Emissions Trading Schemes and Their Linking: Challenges and Opportunities in Asia and the Pacific. Asian Development Bank, Manilla, 17-52.

[3] EU (2014) The EU ETS System. European Union, Brussels,1-26.

[4] Wang, P., Dai, H.C., Ren, S.Y., Zhao, D.Q. and Masui, T. (2015) Achieving Copenhagen Target through Carbon Emission Trading: Economic Impacts Assessment in Guangdong Province of China. Energy, 79, 212-227.

https://doi.org/10.1016/j.energy.2014.11.009

[5] Dormady, N.C. (2014) Carbon Auctions, Energy Markets \& Market Power: An Experimental Analysis. Energy Economics, 44, 468-482. https://doi.org/10.1016/j.eneco.2014.03.013

[6] Zhang, M.S., Liu, Z.L., van Dijk, M.P. (2017) $\mathrm{CO}_{2}$ Emission Trading in China, Can the Market Become a National One, Four Years after Creating Seven Local Markets? Unofficial Publication, Beijing, 17-18.

[7] Liao, Z., Zhu, X. and Shi, J. (2014) Case Study on Initial Allocation of Shanghai Carbon Emission Trading Based on Shapley Value. Journal of Cleaner Production, 103, 338-344. https://doi.org/10.1016/j.jclepro.2014.06.045

[8] Ermolieva, T., Ermoliev, Y., Fischer, G., Jonas, M., Makowski, M. and Wagner, F. (2011) Carbon Emission Trading and Carbon Taxes under Uncertainties. Climate Change, 103, 277-289. https://doi.org/10.1007/s10584-010-9910-x

[9] Duan, M.S., Pang, T. and Zhang X.L. (2014) Review of Carbon Emissions Trading Pilots in China. Energy \& Environment, 25, 527-549. https://doi.org/10.1260/0958-305X.25.3-4.527

[10] Guo J., Zhang, Z.K. and Meng L. (2012) China's Provincial $\mathrm{CO}_{2}$ Emissions Embodied in International and Interprovincial Trade. Energy Policy, 42, 486-497. https://doi.org/10.1016/j.enpol.2011.12.015

[11] Jiang, J., Ye, B. and Ma, X.M. (2014) The Construction of Shenzhen's Carbon Emission Trading Scheme. Energy Policy, 75, 17-21. https://doi.org/10.1016/j.enpol.2014.02.030

[12] Feng, K., Davies, S.J., Sun, L.X., Li, X., Guan, D.B., Liu, W.D. and Liu, Z. (2013) Outsourcing $\mathrm{CO}_{2}$ within China. Proceedings of the National Academy of Science (PNAS), 110, 11654-11659. https://doi.org/10.1073/pnas.1219918110

[13] Wu, L.B., Qian, H.Q. and Li, J. (2014) Advancing the Experiment to Reality: Perspectives on Shanghai Pilot Carbon Emissions Trading Scheme. Energy Policy, 75, 22-30. https://doi.org/10.1016/j.enpol.2014.04.022

[14] Jotzo, F. (2013) Emissions Trading in China: Principles, Design Options and Lessons from International Practice. Working Paper No. 1303, Centre for Climate Economics and Policy (CCEP), Crawford School of Public Policy, Australian National University, Canberra. 